\title{
Взаимодействие фторуглерода с моноокисью кремния и процессы образования нанонитей SiC
}

\author{
() Е.В. Астрова, В.П. Улин, А.В. Парфеньева, А.В. Нащекин, В.Н. Неведомский, М.В. Байдакова \\ Физико-технический институт им. А.Ф. Иофрфе Российской академии наук, \\ 194021 Санкт-Петербург, Россия \\ E-mail: east@mail.ioffe.ru
}

Поступила в Редакцию 6 апреля 2020 г.

В окончательной редакции 12 апреля 2020 г.

Принята к публикации 12 апреля 2020 г.

При изучении процессов термической карбонизации моноокиси кремния в присутствии нестехиометрического монофторида углерода было обнаружено, что повышение температуры отжига смесей порошков $\mathrm{SiO}$ и $\mathrm{CF}_{x}$ в квазизамкнутом объеме до $1000^{\circ} \mathrm{C}$ и выше ведет к выделению нитевидных нанокристаллов $\mathrm{SiC}$. Проведенные исследования показали, что параллельно с известным процессом кристаллизации нанонитей $\mathrm{SiC}$ в результате взаимодействия паров $\mathrm{SiO}$ с угарным газом в их образовании принимает участие неописанное ранее взаимодействие $\mathrm{CO}$ с газофазным дифторидом кремния $\mathrm{SiF}_{2}$. При температурах ниже $1200^{\circ} \mathrm{C}$ эта реакция оказывается доминирующей, давая наибольший вклад в выход нанонитей $\mathrm{SiC}$.

Ключевые слова: образование нанонитей (вискеров) карбида кремния, моноокись кремния, фторуглерод, газофазный дифторид кремния.

DOI: $10.21883 / F T P .2020 .08 .49647 .9402$

\section{1. Введение}

Одномерные нанокристаллы (вискеры) карбида кремния обладают уникальными прочностными характеристиками, высокой химической и термической стабильностью, а также проявляют свойства широкозонного полупроводника и пьезоэлектрика. Все это делает их перспективным материалом для разнообразных технических применений. Так, $\mathrm{SiC}$-нанонити успешно используются как упрочняющая добавка в керамических и металлокерамических композитах [1]. В последнее время появляются многочисленные исследования, демонстрирующие возможность применения их для изготовления полевых эмиттеров, суперконденсаторов, полевых транзисторов, датчиков давления, фотокатализаторов, супергидрофобных покрытий и т.д. [2]. Недавно было опубликовано сообщение о кремниевом материале Advano для анодов Li-ионных аккумуляторов, содержащем нанонити карбида кремния, которые, как утверждают авторы, обеспечивают механическую стабильность композита при изменении объема кремниевых частиц в процессе литирования и делитирования [3].

Существует множество методов газофазного синтеза карбида кремния, обеспечивающих образование нанонитей, в которых используется совместный высокотемпературный пиролиз различных кремний- и углеродсодержащих соединений $[2,4,5]$. Однако наиболее простым методом получения $\mathrm{SiC}$-нанонитей является карботермическое восстановление $\mathrm{SiO}_{2}$, что также требует достаточно высоких температур $1300-1700^{\circ} \mathrm{C}$ [6-9]. При этом предполагается, что $\mathrm{SiO}_{2}$ первоначально восстанавливается до моноокиси кремния $\mathrm{SiO}$, переходящей при этих температурах в газовую фазу и реагирующей затем с выде- ляющейся в том же процессе моноокисью углерода СО:

$$
\begin{gathered}
\mathrm{SiO}_{2}(\mathrm{~s})+\mathrm{C}(\mathrm{s})=\mathrm{SiO}(\mathrm{g})+\mathrm{CO}(\mathrm{g}), \\
\mathrm{SiO}(\mathrm{g})+3 \mathrm{CO}(\mathrm{g})=\mathrm{SiC}(\mathrm{s})+2 \mathrm{CO}_{2}(\mathrm{~g})
\end{gathered}
$$

и(или)

$$
3 \mathrm{SiO}(\mathrm{g})+\mathrm{CO}(\mathrm{g})=\mathrm{SiC}(\mathrm{s})+2 \mathrm{SiO}_{2}(\mathrm{~s}) .
$$

В зависимости от соотношения исходных компонентов и температуры в конденсирующемся из газовой фазы продукте кроме карбида кремния может присутствовать и двуокись кремния.

Протяженные $\mathrm{SiC}$-нанонити образуются, как правило, по механизму пар-жидкость-твердое тело (VLS) в присутствии на субстрате микрокапель расплавакатализатора, активно абсорбирующего из паровой фазы молекулы реагентов ( $\mathrm{SiO}$ и $\mathrm{CO}$ ). При достижении критической величины пересыщения жидкой фазы зародившийся на границе с субстратом кристаллит $\mathrm{SiC}$ продолжает свой рост уже однонаправленно. Это происходит вдоль выделенного кристаллографического направления $(\langle 111\rangle$ или $\langle 0001\rangle$ для гексагональных политипов), соответствующего ростовой поверхности с минимальной величиной свободной поверхностной энергии [10]. В случае карбида кремния тот же фактор выраженной анизотропии свободной поверхностной энергии граней кристалла иногда оказывается достаточным для формирования нанонитей из первичных зародышей и без участия жидкофазного катализатора, непосредственно по механизму пар-твердое тело (VS) [2,11]. Тем не менее скорости роста и аспектные отношения длины к диаметру у таких кристаллов оказываются существенно меньше, чем у выросших по VLS-механизму.

Недавно для получения композитного $\mathrm{Si}-\mathrm{C}$-анодного материала для литий-ионных аккумуляторов нами бы- 
a

b
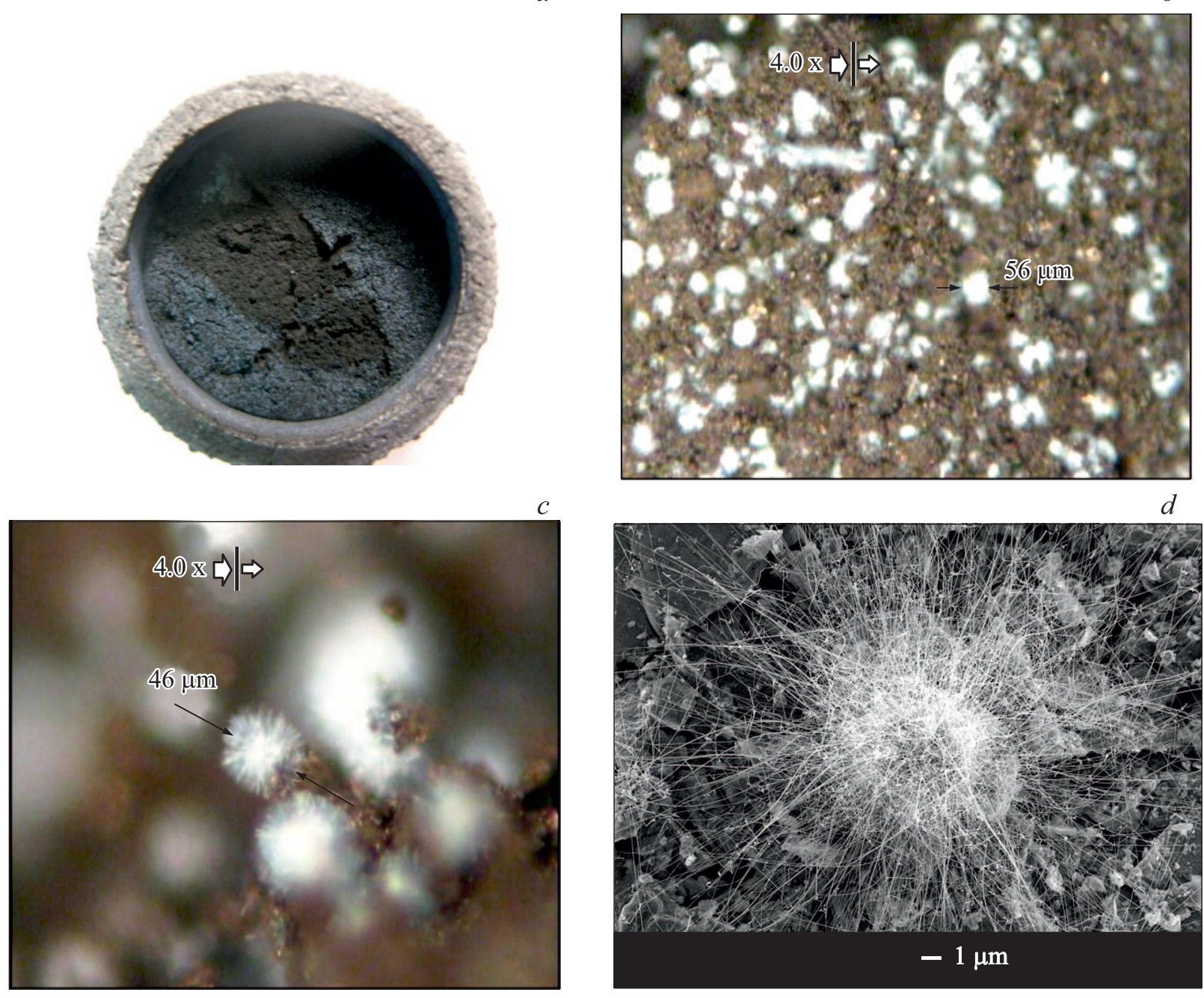

e
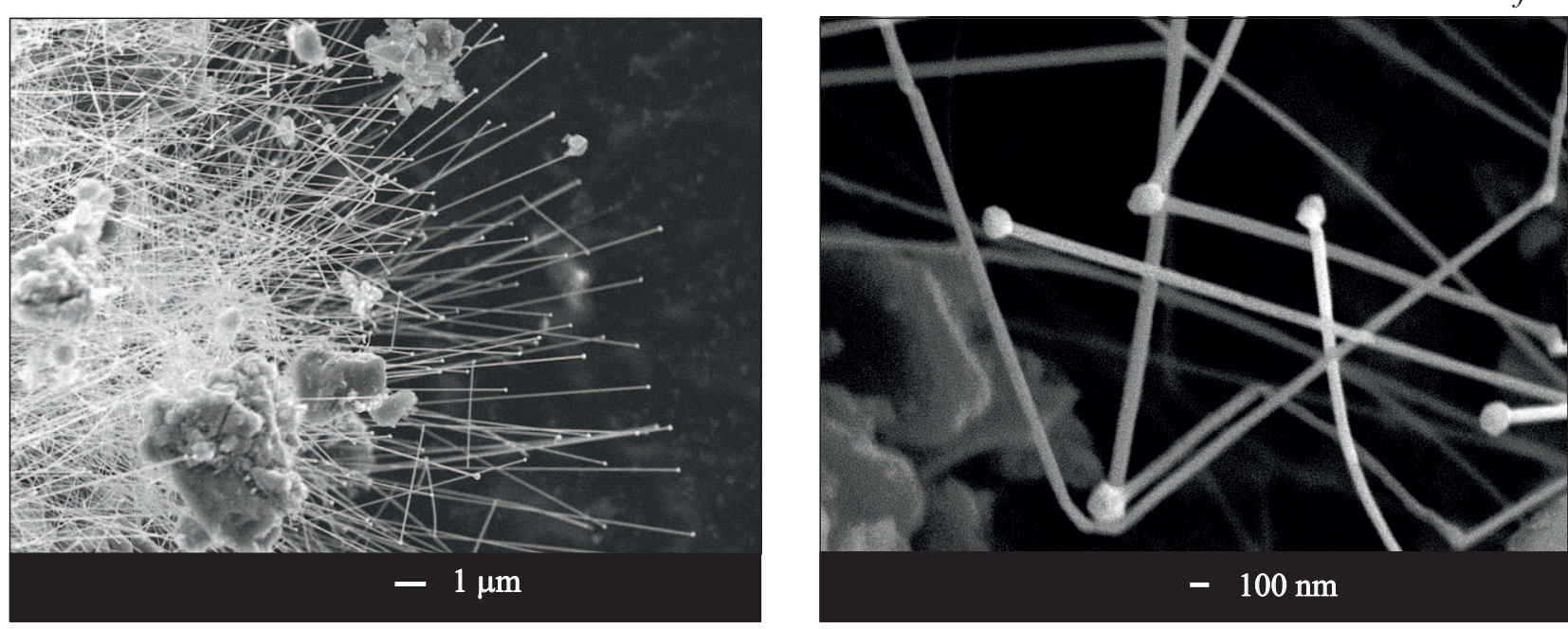

Рис. 1. Нанонити, образовавшиеся при отжиге смеси порошков $\mathrm{SiO}+\mathrm{CF}_{0.8}=40+60$ вес\% при $1150^{\circ} \mathrm{C}: a-$ в виде голубого налета (на фото - в круглой графитовой кассете, где в центральной части верхний слой порошка удален); $b, c-$ оптические изображения области с голубым налетом при разном увеличении; $d$, $e$ и $f$ - SEM-изображения „ежика“ и отдельных нанонитей. 

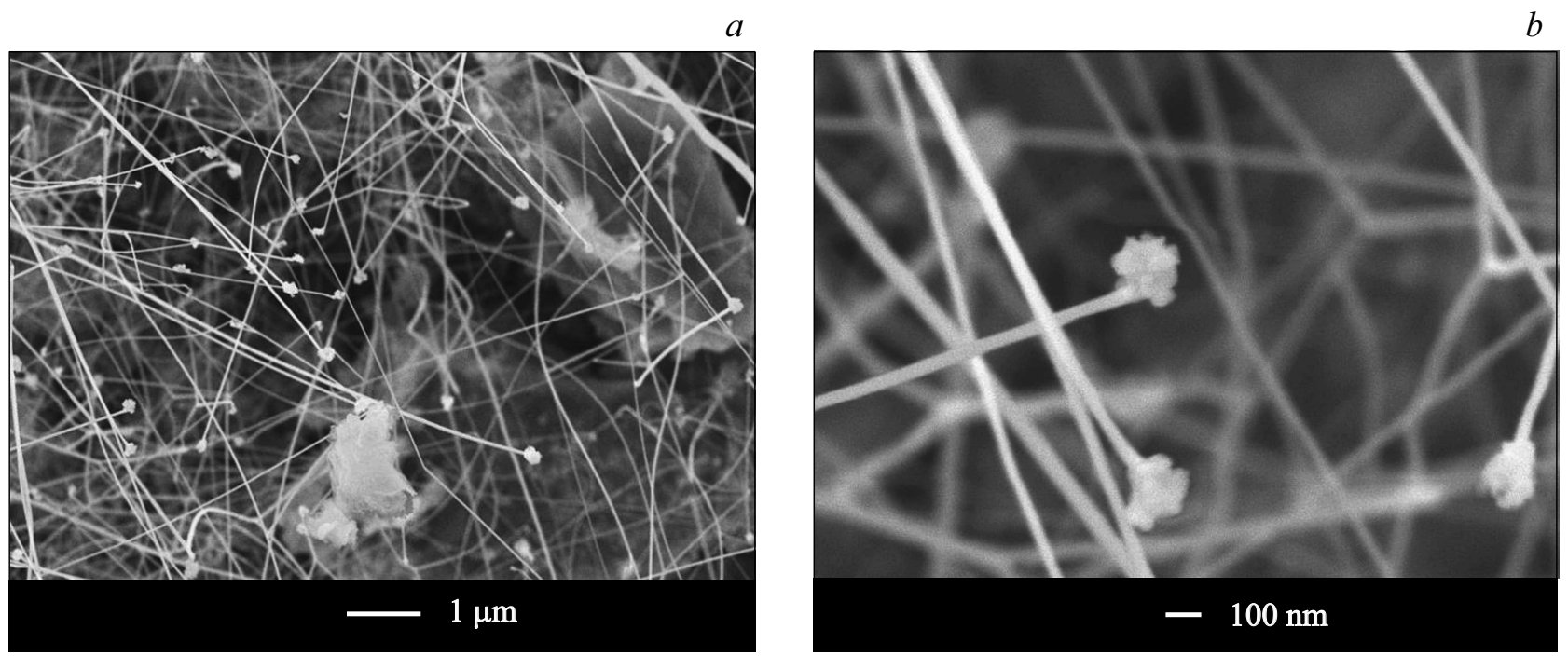

Рис. 2. Нанонити, образовавшиеся на поверхности таблеток, изготовленных из смеси $\mathrm{SiO}+\mathrm{CF}_{0.8}=70+30$ вес\%. На конце нитей наросты неправильной формы, состоящие из нескольких более мелких частиц.

ло предложено проводить карбонизацию частиц нанодисперсного кремния путем их совместного отжига с нестехиометрическим монофторидом углерода $\mathrm{CF}_{x}$ при относительно низких температурах $\left(460-800^{\circ} \mathrm{C}\right)[12,13]$. Было также показано, что дополнительный отжиг полученного композита при более высокой температуре $\left(\geq 1100^{\circ} \mathrm{C}\right)$ ведет к образованию на кремниевых частицах карбида кремния кубической модификации [14]. В настоящей работе при изучении аналогичных процессов карбонизации моноокиси кремния фторуглеродом с последующим высокотемпературным отжигом мы обнаружили, что в конечном продукте появляются нанонити карбида кремния. Проведенные исследования показали, что наряду с известными процессами образования нанонитей $\mathrm{SiC}$ согласно реакциям (1)-(3), в присутствии образующихся фторидов кремния рост нанонитей развивается также за счет взаимодействия моноокиси углерода с дифторидом кремния $\left(\mathrm{SiF}_{2}\right)$. При температурах ниже $1200^{\circ} \mathrm{C}$ такая реакция становится основной и протекает с существенно большим выходом.

\section{2. Исходные материалы и методика исследований}

Исходным материалом служил порошок фторуглерода состава $\mathrm{CF}_{0.8}$ (Галополимер) с размером частиц 0.3-5 мкм, который смешивали с порошком моноокиси кремния $\mathrm{SiO}$ марки ОСЧ (размер частиц 80-200 мкм) или с $\mathrm{SiO}_{2}$ в форме аэросила (размер частиц $\sim 10 \mathrm{Hм}$ ). Порошки, взятые в нужной весовой пропорции, измельчали и тщательно перемешивали в агатовой ступке. Из полученных смесей путем холодной компрессии при давлении 180 МПа изготавливали таблетки диаметром 10 мм. Таблетка или навеска из смеси порошков по- мещалась в графитовую кассету с плотно прилегающей крышкой (квазизамкнутый объем) и отжигалась в кварцевой трубе, продуваемой чистым аргоном. В режиме медленного нагрева скорость повышения температуры равнялась 3.3 град/мин, в случае быстрого $\sim 100$ град/мин; выдержка при максимальной температуре составляла 1 ч.

Исследования структуры и состава продуктов проводились с помощью оптического микроскопа Nikon в режиме темного поля, растрового электронного микроскопа (SEM) JSM 7001F (JEOL, Япония), оснащенного системой рентгеноспектрального микроанализа (EDX) INCA PentaFETx3 (Oxford Instruments, Англия). Для исследования с помощью просвечивающей электронной микроскопии (ТЕМ) использовался микроскоп ЈЕМ $2100 \mathrm{~F}$ (JEOL, Япония) при ускоряющем напряжении 200 кВ. После измельчения и диспергирования образца в ультразвуковой ванне взвешенные частицы улавливались медной сеткой, покрытой пленкой графеноподобного углерода. Рентгенодифракционные исследования проводились на порошковом дифрактометре D2 Phaser, Bruker (CuK-излучение). Дифрактограммы анализировались с использованием программы DIFFRAC.EVA и встроенной базы данных порошковой дифрактометрии „Powder Diffraction File ICCD PDF-2 release“ [15].

\section{3. Образование нанонитей}

При изучении продуктов отжига смесей $\mathrm{SiO}+\mathrm{CF}_{0.8}$ было обнаружено, что высокотемпературный отжиг $\left(>1100^{\circ} \mathrm{C}\right)$ приводит к появлению голубого налета на поверхности порошка или предварительно спрессованных таблеток (рис. 1,a). При ближайшем рассмотрении стало понятно, что этот налет состоит из дискретных образований в виде „ежиков“, диаметром 40-60 мкм 

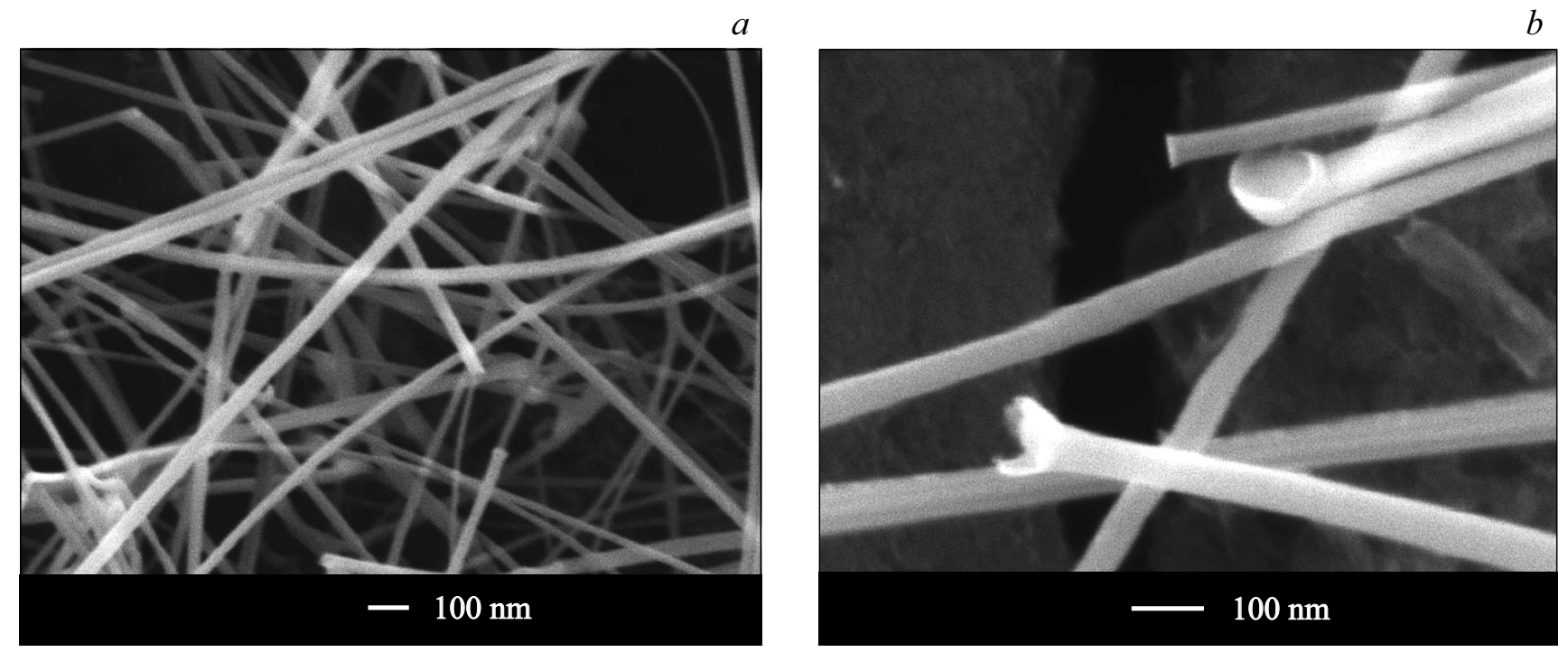

Pис. 3. SEM-изображения нанонитей после обработки: $a-$ в водном растворе $\mathrm{HF}(1: 1) 16.5$ ч; $b-$ в парах HF 5.5 ч.

(рис. $1, b, c)$, образованных скоплениями прямых или изогнутых нанонитей диаметром 12-55 нм и длиной до 20 мкм, исходящих из общего центра (рис. $1 d, e, f)$.

Эксперименты показали, что повышение температуры отжига способствует увеличению плотности выделений и количества нанонитей. На конце каждой нанонити присутствует сферический нарост (рис. $1, e, f)$ или нарост более сложной формы (рис. 2). Наличие шарика на конце нанонити свидетельствует о том, что образование нитей происходит по VLS-механизму, хотя никаких специальных каталитических добавок мы не вводили. В результате обработки в плавиковой кислоте или в ее парах сами нити не изменяются, тогда как шарики на их концах исчезают или частично разрушаются (рис. 3 ). Bce это позволяет думать, что наблюдаемые шарики образованы каплями силикатного расплава.

Исходные таблетки из смеси $\mathrm{SiO}+\mathrm{CF}_{0.8}$ и прошедшие термообработку при температуре 1000 и $1150^{\circ} \mathrm{C}$ были исследованы методом рентгеновской дифрактометрии. На рис. 4 приведены полученные рентгенограммы, свидетельствующие о появлении в результате высокотемпературного отжига выделений карбида кремния кубической модификации $\beta$-SiC (JCPDS № 00-029-1129), суммарный объем которых увеличивается с повышением температуры. Наблюдаемые на рентгенограммах рефлексы могут быть соотнесены как с нанонитями, так и с компактными формами кристаллитов карбида кремния.

ТЕМ-исследования выделенных из продуктов отжига нанонитей $\mathrm{SiC}$ показали, что они имеют кристаллическую структуру (см. рис. 5) и в большинстве своем состоят из чередующихся микроскопических фрагментов кубической и гексагональных фаз. В пределах таких фазовых фрагментов часто обнаруживаются дефекты упаковки и двойниковые границы, ориентированные в плоскости ортогональной направлению роста нанонити. Реже встречаются нанонити с протяженными участками,

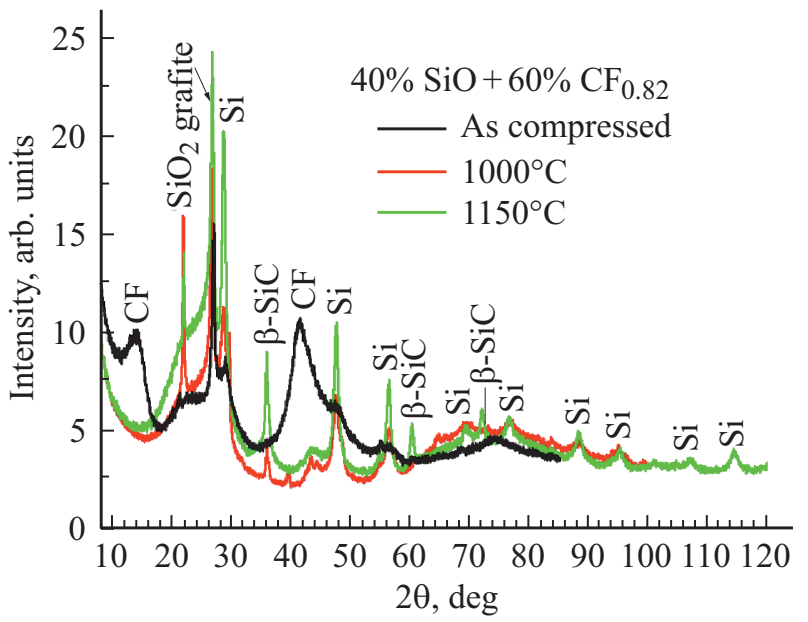

Рис. 4. Рентгенограмма таблетки до и после отжига при $T=1000$ и $1150^{\circ} \mathrm{C}$.

не содержащими таких дефектов. На ТЕМ-изображениях высокого разрешения (рис. 5,b) выявляются системы плоскостей, ориентированных параллельно, перпендикулярно и под углом $\sim 20^{\circ}$ к оси вискера (угол между направлением $\langle 111\rangle$ в кубической решетке $\beta$-SiC и семейством неортогональных ему плоскостей $\left.\{111\} 19.47^{\circ}\right)$. По этим изображениям были измерены межплоскостные расстояния, которые составили $2.63,2.51$ и $2.51 \AA$, соответственно. Межплоскостное расстояние $d=2.518 \AA$ встречается во многих политипах $\mathrm{SiC}$ и может принадлежать как кубической $\beta$-SiC, плоскости $\{111\}$, (JCPDS № 00-029-1129), так и гексагональной фазе (JCPDS № 00-029-1131). Причем в гексагональной фазе $6 H$ этим расстоянием характеризуются два различных семейства плоскостей: $\{101 \overline{2}\}$ и $\{0006\}$. Межплоскостное расстояние $d=2.63 \AA$ не может принадлежать кубическому 
$a$
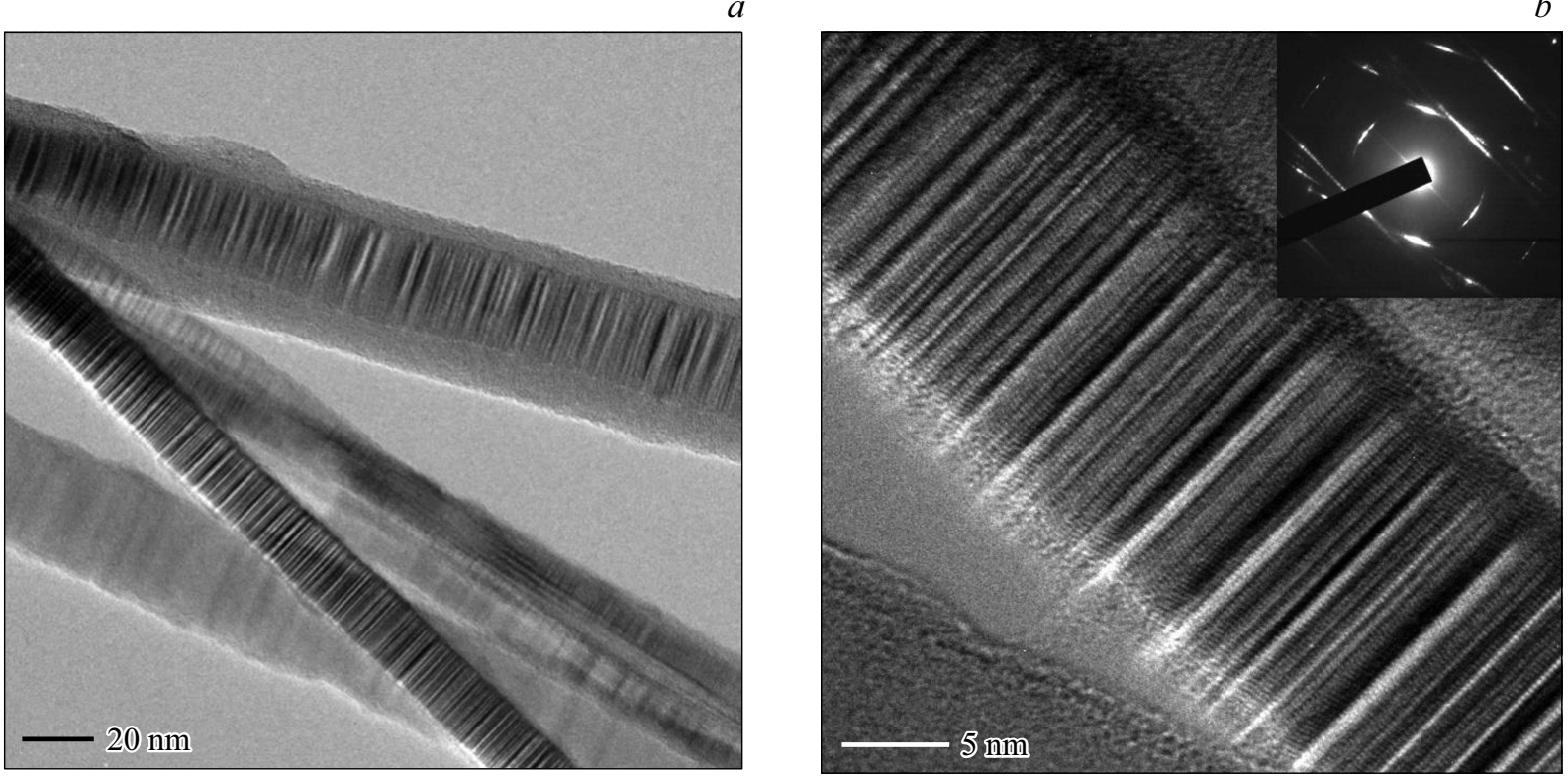

Рис. 5. ТЕМ-изображения: $a$ - нанонитей с аморфной оболочкой и без нее; $b-$ нанонить с чередованием фрагментов различной фазовой принадлежности и дефектами упаковки. Соответствующая ей дифракционная картина представлена на вставке.

$a$
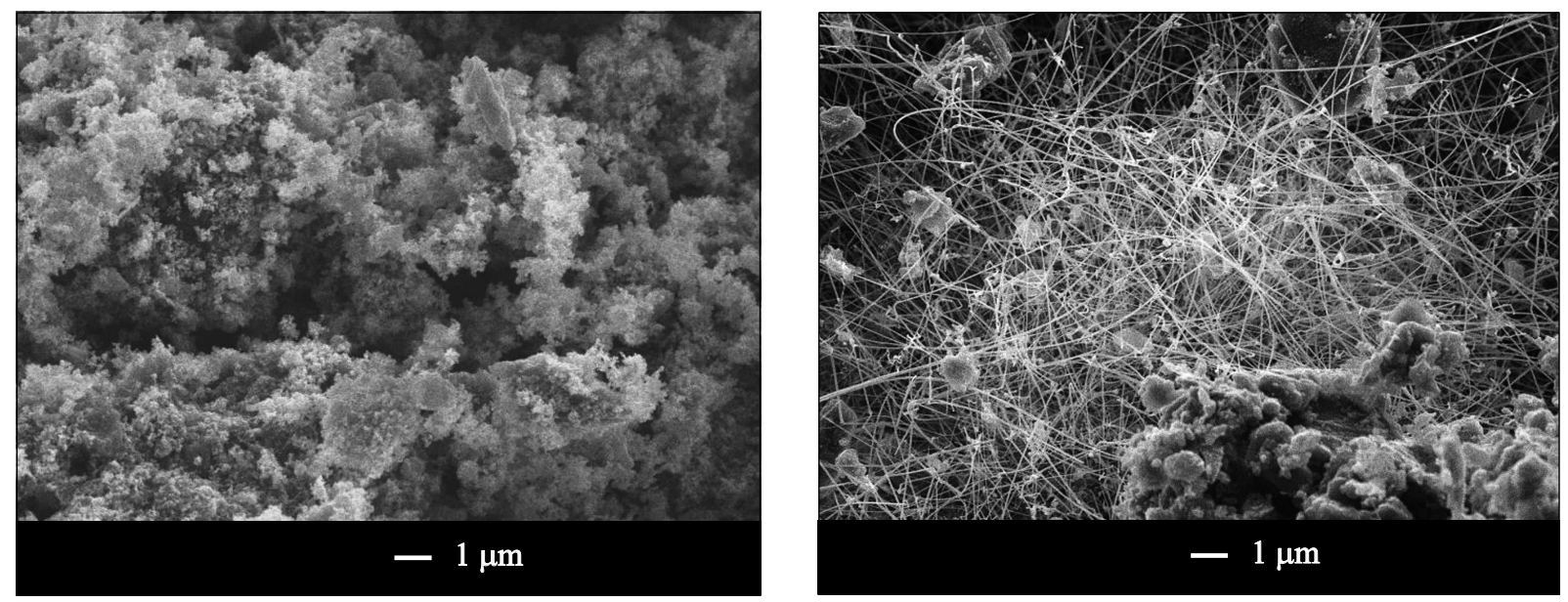

C

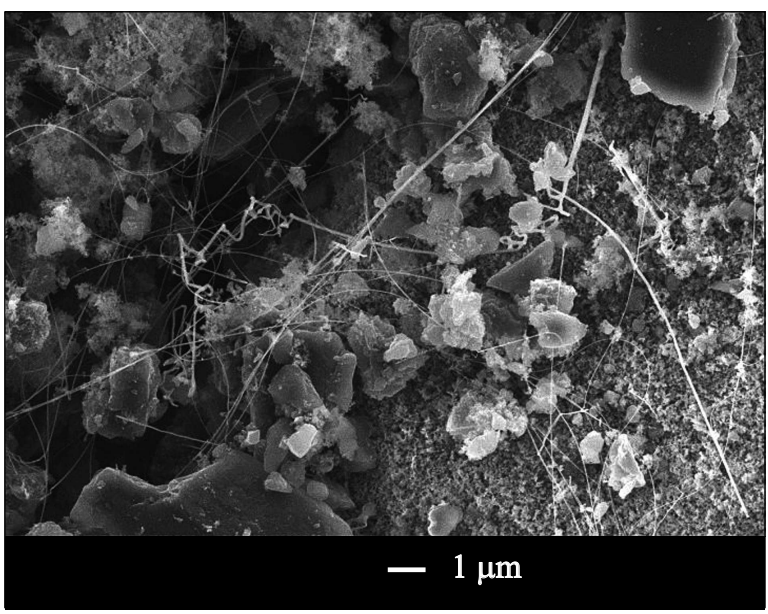

Рис. 6. SЕМ-изображения смеси фторуглерода с различными кремниевыми компонентами после отжига при $T=1200^{\circ} \mathrm{C}$ : $a-\mathrm{Si}+\mathrm{CF}_{0.8}(29+71 \mathrm{веc} \%) ; b-\mathrm{SiO}+\mathrm{CF}_{0.8}(49+51 \mathrm{веc} \%) ; c-\mathrm{SiO}_{2}+\mathrm{CF}_{0.8}(47+53 \mathrm{вec} \%)$. 

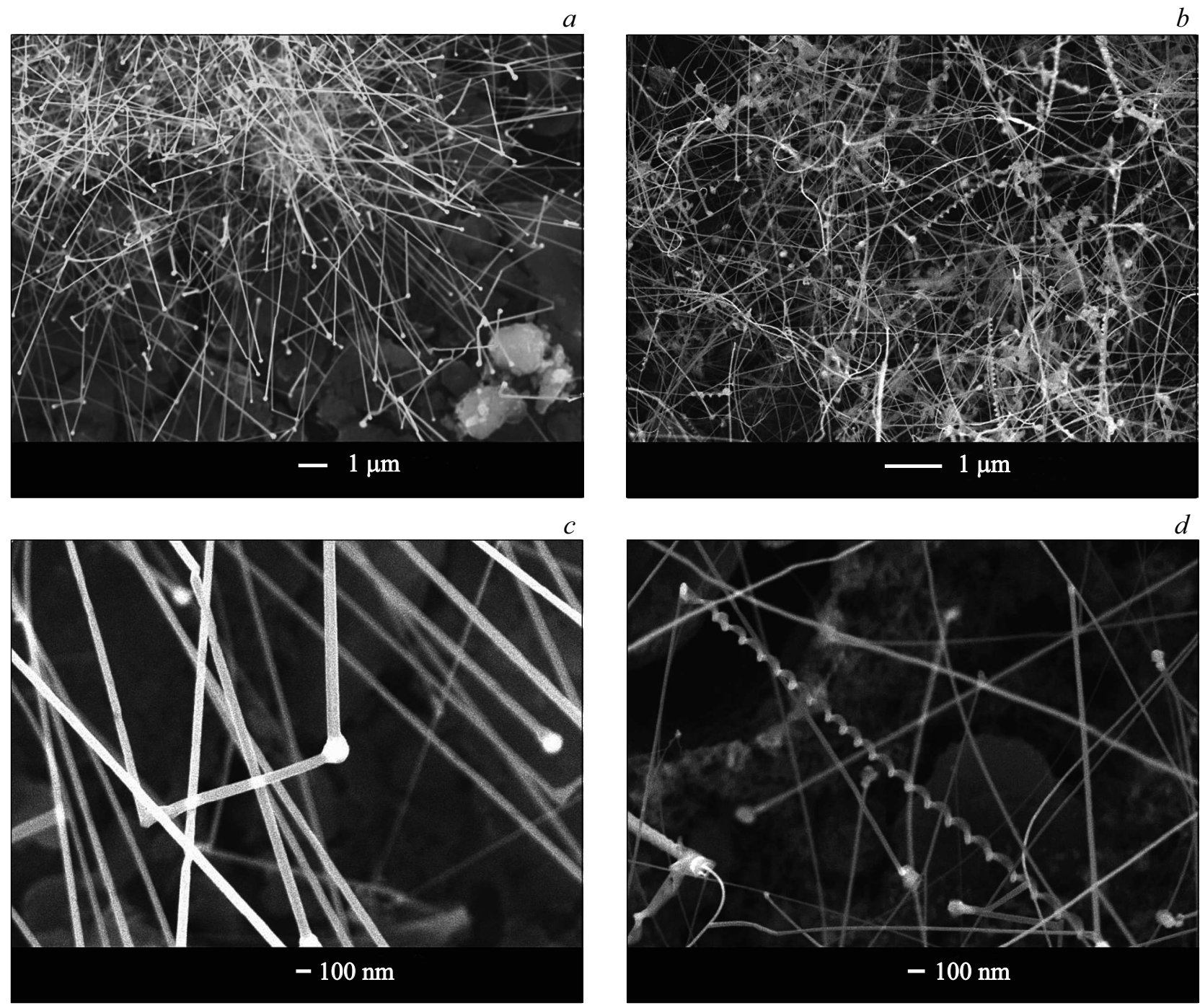

Рис. 7. Форма нанонитей, образовавшихся на поверхности отожженных таблеток, содержавших $\mathrm{CF}_{0.8}$ с 30 мол\% $\mathrm{SiO}(a, c)$ и с 30 мол\% $\mathrm{SiO}_{2}(b, d)$. Отжиг проводился в два этапа: первоначально с использованием медленного нагрева до $800^{\circ} \mathrm{C}$, а затем при быстром нагреве до $1150^{\circ} \mathrm{C}$.

политипу $\mathrm{SiC}$, при этом достаточно хорошо совпадает с межплоскостным расстоянием для плоскостей $\{101 \overline{1}\}$ в политипе $6 \mathrm{H}$-SiC.

На картинах электронной дифракции, полученных от нанонитей, рефлексы обратной решетки представляют собой тяжи, которые возникают из-за дефектов упаковки. Такая размазанность узлов обратной решетки затрудняет точные измерения углов между ними. Тем не менее по дифракционным картинам дополнительно было выявлено еще несколько межплоскостных расстояний: 2.40, $2.02,1.85$ и $1.39 \AA$, которые могут быть приписаны политипу $6 H$-SiC и подобных ему с гексагональной структурой (например, $4 H$ - $\mathrm{SiC}, 2 H-\mathrm{SiC}$ ), однако при этом нельзя полностью исключать наличие других политипов. Боковые поверхности нанонитей выглядят ровными, не имеющими выступов, которые могли бы образовываться на стыках сформировавшихся плоскостей с различающимися индексами Миллера. Следует также отметить, что некоторые из нитей покрыты аморфной оболочкой, присутствие которой заметно не сказывается на наличии фазовых фрагментов и плотности дефектов упаковки (рис. 5,a). Появление такой оболочки можно, по-видимому, связать с локальными и(или) временными вариациями соотношения в газовой фазе реагирующих компонентов $\mathrm{SiO}$ и СО. Как следует из стехиометрии реакций (2) и (3), этим соотношением должна определяться вероятность совместного осаждения $\mathrm{SiC}$ и $\mathrm{SiO}_{2}$.

\section{4. Взаимодействие фторуглерода с кремнием и его оксидами}

Мы проследили за появлением нанонитей $\mathrm{SiC}$ при отжиге в одинаковых условиях фторуглерода с $\mathrm{Si}, \mathrm{SiO}$ и $\mathrm{SiO}_{2}$. Для этого использовались гомогенизированные смеси из порошков компонентов, взятых в соотноше- 
ниях, отвечающих стехиометрии соответствующих суммарных реакций:

$$
\begin{gathered}
2 \mathrm{Si}(\mathrm{s})+5 \mathrm{CF}_{0.8}(\mathrm{~s})=\mathrm{SiC}(\mathrm{s})+\mathrm{SiF}_{4}(\mathrm{~g})+4 \mathrm{C}(\mathrm{s}) \\
3 \mathrm{SiO}(\mathrm{s})+5 \mathrm{CF}_{0.8}(\mathrm{~s})=2 \mathrm{SiC}(\mathrm{s})+\mathrm{SiF}_{4}(\mathrm{~g})+3 \mathrm{CO}(\mathrm{g}) \\
2 \mathrm{SiO}_{2}(\mathrm{~s})+5 \mathrm{CF}_{0.8}(\mathrm{~s})=\mathrm{SiC}(\mathrm{s})+\mathrm{SiF}_{4}(\mathrm{~g})+4 \mathrm{CO}(\mathrm{g})
\end{gathered}
$$

На рис. 6 показано изображение поверхности смесей после отжига при $1200^{\circ} \mathrm{C}$, на которых видно, что в случае кремния, когда в продуктах взаимодействия нет моноокиси углерода, нанонити не образуются. При сравнении продуктов реакций фторуглерода с $\mathrm{SiO}$ и $\mathrm{SiO}_{2}$ видно, что наибольшее количество нанонитей появляется из смеси, содержащей моноокись кремния. Более детальное изучение нанонитей, сформировавшихся в системах $\left(\mathrm{CF}_{0.8}+\mathrm{SiO}\right)$ и $\left(\mathrm{CF}_{0.8}+\mathrm{SiO}_{2}\right)$, показало, что по своей морфологии выросшие нанонити несколько различаются. Из рис. 7 видно, что в случае с $\mathrm{SiO}$ нити $\mathrm{SiC}$ прямолинейные и более толстые, чем в варианте с $\mathrm{SiO}_{2}$, где они заметно тоньше и часто вырастают изогнутыми, а некоторые даже скрученными в спираль.

Дальнейшие эксперименты проводились с моноокисью кремния, как наиболее продуктивным прекурсором. При этом было отмечено, что увеличение доли $\mathrm{SiO}$ в исходных смесях приводит к возрастанию количества выделений $\mathrm{SiC}$ в виде скоплений нанонитей („ежиков“). Рассмотрим более подробно химические процессы, приводящие к образованию $\mathrm{SiC}$-нанонитей при взаимодействии $\mathrm{SiO}$ с фторуглеродом.

\section{5. Разложение монофторида углерода и низкотемпературная карбонизация SiO}

Взаимодействие нестехиометрического монофторида углерода $\mathrm{CF}_{x}$ c $\mathrm{SiO}$ начинается уже при относительно низкой температуре, $<500^{\circ} \mathrm{C}$, и протекает экзотермически, так что при быстром нагреве может сопровождаться взрывом. Поэтому, начиная с $400^{\circ} \mathrm{C}$, использовался медленный нагрев смесей. В интервале температур до $1000^{\circ} \mathrm{C}$ конечным твердофазным продуктом последовательно протекающих в системе процессов оказывается лишь элементарный углерод. Суммарное уравнение происходящих реакций может быть записано следующим образом:

$$
\mathrm{SiO}(\mathrm{s})+4 / x \mathrm{CF}_{x}(\mathrm{~s})=\mathrm{SiF}_{4}(\mathrm{~g})+(4-x) / x \mathrm{C}(\mathrm{s})+\mathrm{CO}(\mathrm{g}) .
$$

Начальным этапом этого процесса служит термическое разложение твердофазного монофторида углерода с выделением активных молекул летучих фторидов углерода:

$$
v / x \mathrm{CF}_{x}(\mathrm{~s})=(v-w x) / x \mathrm{C}(\mathrm{s})+\mathrm{C}_{w} \mathrm{~F}_{v}(\mathrm{~g})
$$

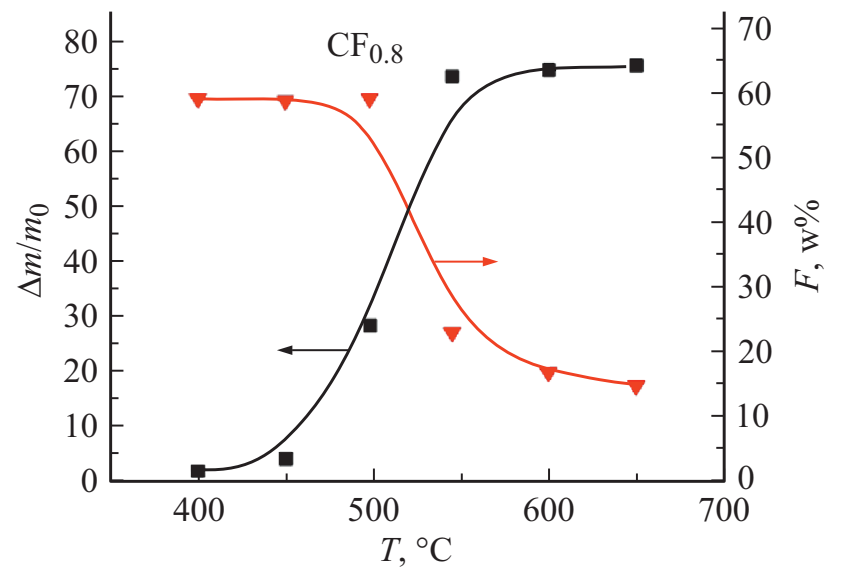

Рис. 8. Потеря массы и изменение содержания фтора в таблетке из фторуглерода $\mathrm{CF}_{0.8}$ в зависимости от температуры.

По изменению массы и состава отдельно взятого фторуглерода в процессе его термической диссоциации при различных температурах можно определить средний состав выделяющихся газообразных молекул $\mathrm{C}_{w} \mathrm{~F}_{v}$. На рис. 8 приведена зависимость, из которой следует, что степень диссоциации твердофазного $\mathrm{CF}_{x}$ резко возрастает в диапазоне $T=450-600^{\circ} \mathrm{C}$. Для $T>600^{\circ} \mathrm{C}$ зависимость потери массы $\mathrm{CF}_{0.8}$ от температуры выходит на полочку при значениях $\Delta m / m_{0} \sim 75 \%$. Следует обратить внимание, что при этом в твердом продукте диссоциации все еще содержится до 15 вес\% фтора (10 ат\% F). Усредненное соотношение фтора к углероду в выделившихся газообразных продуктах диспропорционирования оценивалось в соответствии с уравнением

$$
\mathrm{CF}_{0.8}(\mathrm{~s})=a \mathrm{CF}_{k}(\mathrm{~s})+(1-a) \mathrm{CF}_{v}(\mathrm{~g}),
$$

где $a=n_{\mathrm{CF}_{k}} / n_{\mathrm{CF}_{0.8}}=m_{f} \mu_{0} / m_{0} \mu_{f}$, где $\mu_{0}$ и $\mu_{f}-$ приведенные молекулярные массы формульной единицы исходного и оставшегося фторуглеродов, $m_{0}$ и $m_{f}$ - их исходный и конечный вес. Если $\Delta m / m_{0}$ относительная убыль веса отожженного $\mathrm{CF}_{0.8}$, то $a=\left(1-\Delta m / m_{0}\right) \mu_{0} / \mu_{f} \quad$ и $\quad v=(0.8-a k) /(1-a)$. Согласно полученным данным для $650^{\circ} \mathrm{C}, \Delta m / m_{0}=0.76$ и $k=0.11$, откуда $a=0.48$ и $v=1.49$. Соответственно, в летучих продуктах термической диссоциации $\mathrm{CF}_{0.8}$ должны доминировать молекулы с $1 \leq v \leq 2$, т.е. $\mathrm{C}_{2} \mathrm{~F}_{2}$, $\mathrm{C}_{3} \mathrm{~F}_{4}$ и $\mathrm{C}_{2} \mathrm{~F}_{4}$.

Аналогичные температурные зависимости убыли суммарной массы компонентов и снижения содержания в них фтора для реакции моноокиси кремния со фторуглеродом приведены на рис. 9. Несмотря на то что температурный интервал резкого изменения массы и состава смеси примерно тот же, что и в случае чистого $\mathrm{CF}_{0.8}$, очевидно, что в присутствии $\mathrm{SiO}$ реакция начинается при более низкой температуре. Так, при $400^{\circ} \mathrm{C} \Delta m / m_{0}$ уже отличается от нуля, а температура, соответствующая половине максимальной потери массы $\Delta m / 2 m_{0}$, смещена к меньшим значениям на $24^{\circ}$ от 506 до $482^{\circ} \mathrm{C}$. Следует обратить внимание на то, что для $T=650^{\circ} \mathrm{C}$, даже с 


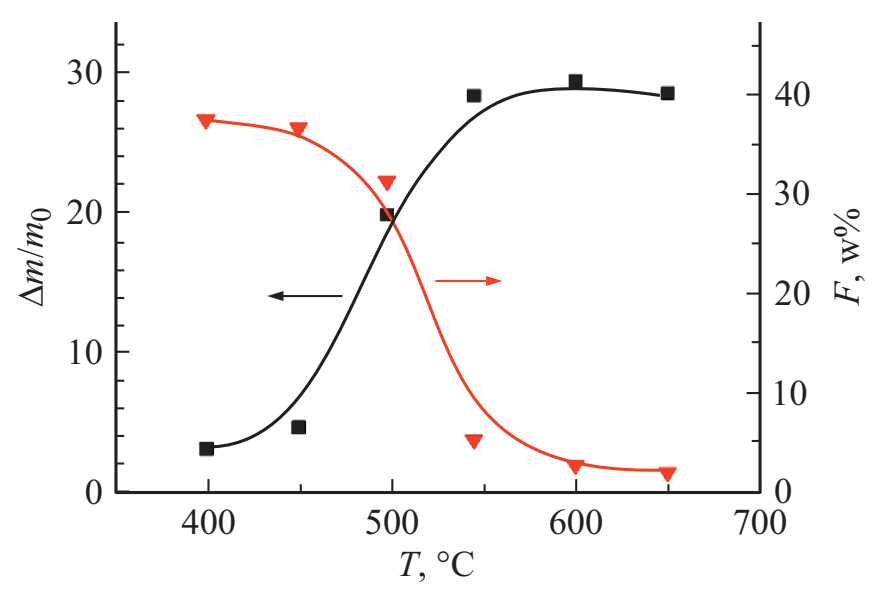

Рис. 9. Потеря массы и изменение количества фтора в твердой фазе в зависимости от температуры отжига таблеток $\mathrm{SiO}+\mathrm{CF}_{0.8}(70+30 \mathrm{Bec} \%)$. учетом наличия в анализируемом продукте непрореагировавшей $\mathrm{SiO}$, количество фтора, остающееся в твердой фазе, явно меньше, чем при разложении чистого фторуглерода. Это свидетельствует об активности протекания уже при этих, относительно невысоких, температурах термодинамически обусловленных процессов, в которых углерод и кремний обмениваются между собой атомами фтора и кислорода.

Из материального баланса реакции (7), где $x=0.8$, а $\mathrm{SiO}$ взята в избытке и составляет $70 \mathrm{веc \%}$ (59.4 мол\%) следует расчетное значение $\Delta m / m_{0}=29.13 \%$, что хорошо согласуется с экспериментом, который дает $\Delta m / m_{0}=29.3 \%$. Из графиков рис. 8 и 9 следует, что при $T<650^{\circ} \mathrm{C}$ углерод, образующийся в результате диспропорционирования чистого $\mathrm{CF}_{0.8}$, а также находившегося в смеси с моноокисью кремния, все еще содержит остаточный фтор, несмотря на то что во втором случае концентрация фтора значительно ниже.
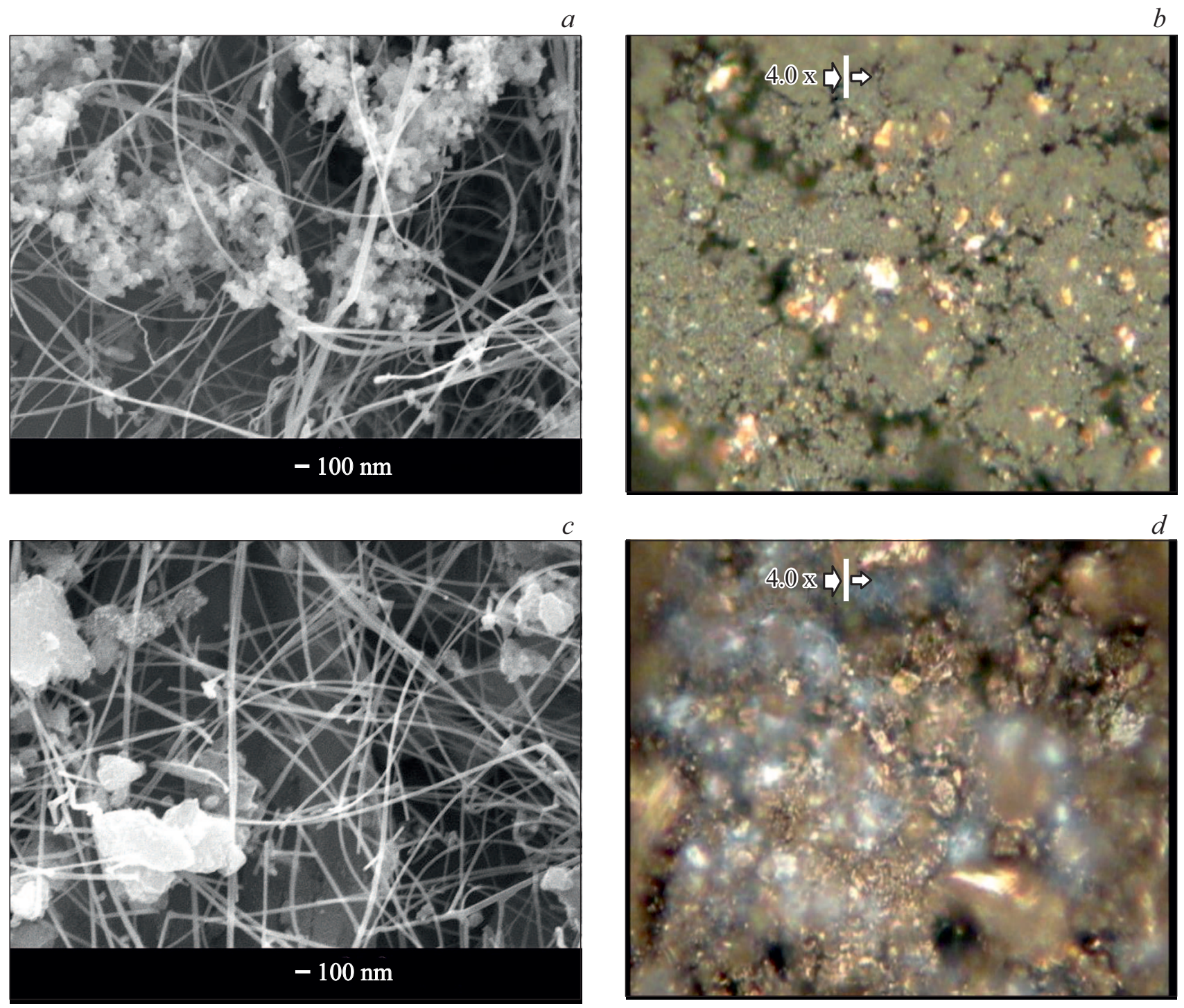

Рис. 10. Изображение областей с нанонитями $\mathrm{SiC}$ в электронном $(a, c)$ и в оптическом микроскопе $(b, d)$ на поверхности отожженных при $1150^{\circ} \mathrm{C}$ смесей $\mathrm{SiO}$ и $\mathrm{C}$ с остаточным фтором $(c, d-$ из серии $\mathrm{UC})$ и без него $(a, b-$ образец из серии $\mathrm{U})$. 


\section{6. Высокотемпературный отжиг и образование нанонитей SiC. Влияние фтора}

Для того чтобы выявить влияние фтора на образование нанонитей $\mathrm{SiC}$, нами использовался двухстадийный отжиг, при котором сначала проводилась медленная низкотемпературная карбонизация моноокиси кремния фторуглеродом, а затем быстрый нагрев смеси до различных температур $>1000^{\circ} \mathrm{C}$. Для этого после первой стадии низкотемпературного отжига кассета с образцами извлекалась из печи, затем печь разогревалась до требуемой температуры, и кассета с образцами быстро задвигалась в рабочую зону. Двустадийный процесс удобен тем, что позволяет вычленить эффекты как низко-, так и высокотемпературных реакций, протекающих в системе $(\mathrm{Si}-\mathrm{O}-\mathrm{C}-\mathrm{F})$.

Для экспериментов серии UC мы использовали смесь $\mathrm{SiO}+\mathrm{CF}_{0.8}=50+50$ вес\%, которую сначала подвергали низкотемпературной обработке при $T=540^{\circ} \mathrm{C}$, при которой в твердофазном продукте оставалось $\sim 10 \mathrm{вес \%}$ фтора (данные EDX). Кассету с карбонизированным таким образом $\mathrm{SiO}$ помещали в высокотемпературную зону печи. В качестве контрольного эксперимента использовалась смесь $\mathrm{SiO}+\mathrm{C}=50+50$ вес\% (монокись кремния + сажа Super C65 Timcal). Эту контрольную смесь, не содержащую фтора, (образцы U) подвергали высокотемпературному отжигу в отдельной кассете одновременно с образцами UC.

При исследовании в электронном микроскопе образцов обоих типов, отжигавшихся при $T>1100^{\circ} \mathrm{C}$, обнаруживались нанонити, которые хорошо видны на SEM-изображениях (рис. 10,a,c). Однако в образцах серии UC их существенно больше, о чем свидетельствуют фотографии, полученные с помощью оптического микроскопа (рис. $10, b, d$ ). Действительно, после отжига при $1150^{\circ} \mathrm{C}$ голубые области с нанонитями видны только в образце UC. Обращает на себя внимание то, что в образце U (рис. 10,a), кроме нанонитей, встречаются конгломераты мелких округлых частиц. $\mathrm{SiC}$ в подобной форме наблюдался в работе [7] под слоем нанонитей, которые получались путем карботермического восстановления двуокиси кремния при $T=1300^{\circ} \mathrm{C}$.

$\mathrm{B}$ несодержащей фтора системе $\mathrm{SiO}+\mathrm{C}$ образование нанонитей с сопоставимым выходом зафиксировано только при существенно более высокой температуре $\left(1250^{\circ} \mathrm{C}\right)$, чем та, что потребовалась для их образования при взаимодействии $\mathrm{SiO}$ со фторсодержащим углеродом $\left(1150^{\circ} \mathrm{C}\right)$. На рис. 11 приведена фотография кассеты, где на порошке и на графитовой крышке хорошо виден голубой налет. В оптическом и электронном микроскопе этот налет выглядит как густая паутина из нанонитей. Как и нанонити, полученные в предыдущих опытах, эти нити также не растворяются в $\mathrm{HF}$, что подтверждает их принадлежность к $\mathrm{SiC}$. Сопоставление полученных наблюдений показывает, что присутствие остаточного фтора, связанного с углеродом, способствует более интенсивному образованию нанонитей карбида кремния.

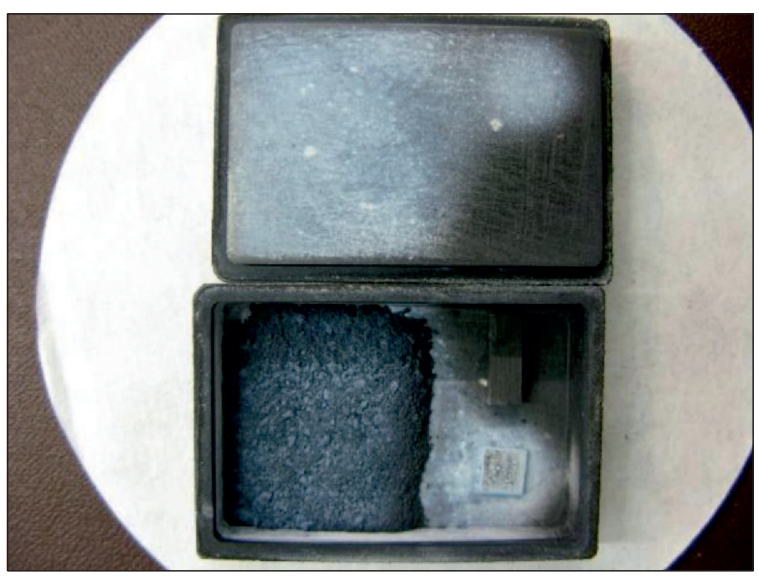

Рис. 11. Графитовая кассета и внутренняя поверхность крышки после отжига порошка $\mathrm{SiO}+\mathrm{C}(1: 1)$ при $T=1250^{\circ} \mathrm{C}$.

Как уже отмечалось, в системах $\left(\mathrm{SiO}_{2}-\mathrm{C}\right)$ и $(\mathrm{SiO}-\mathrm{C})$ формирование нанонитей карбида кремния обеспечивается взаимодействием неполновалентных соединений кремния и углерода: $\mathrm{SiO}$ и $\mathrm{CO}$, которые появляются в газовой фазе при высоких температурах, реакции (2) и (3) $[6,8]$. В нашем же случае уже при $T \sim 1000^{\circ} \mathrm{C}$ значительная часть образующегося по реакции (7) $\mathrm{SiF}_{4}$ может преобразовываться в неполновалентное газообразное соединение кремния $\mathrm{SiF}_{2}$ :

$$
\mathrm{SiF}_{4}(\mathrm{~g})+2 \mathrm{SiO}(\mathrm{s})=2 \mathrm{SiF}_{2}(\mathrm{~g})+\mathrm{SiO}_{2}(\mathrm{~s}) .
$$

Отсутствие сведений о термодинамических постоянных твердофазной $\mathrm{SiO}$ не позволяет дать корректную оценку константе равновесия реакции (10). Однако, так как при $T \geq 1000^{\circ} \mathrm{C}$ конденсированная моноокись кремния термодинамически нестабильна и развивается ее спонтанное диспропорционирование на кремний и двуокись кремния, то равновесные давления дифторида кремния над $\mathrm{SiO}$ при тех же температурных условиях и давлениях тетрафторида кремния не должны кардинально отличаться от равновесных давлений $\mathrm{SiF}_{2}$ над кремнием. Согласно проведенным оценкам для системы $\mathrm{Si}-\mathrm{F}$, при общем давлении в газовой фазе 1 ат, равновесное парциальное давление $\mathrm{SiF}_{2}$ в интервале температур $\left(1000-1200^{\circ} \mathrm{C}\right)$ должно возрастать от 0.123 до 0.594 ат (термические константы компонентов взяты из [16]). Разумно предположить, что взаимодействие дифторида кремния с СО так же, как и взаимодействие газообразной моноокиси кремния с $\mathrm{CO}$, способно приводить к выделению карбида кремния:

$$
2 \mathrm{SiF}_{2}(\mathrm{~g})+2 \mathrm{CO}(\mathrm{g})=\mathrm{SiC}+\mathrm{SiF}_{4}(\mathrm{~g})+\mathrm{CO}_{2}(\mathrm{~g}) .
$$

Кроме того, можно было бы допустить, что появляющиеся при разложении твердофазного фторуглерода непредельные фторуглероды (8), реагируя с парами $\mathrm{SiO}$, также способны участвовать в выделении $\mathrm{SiC}$, например:

$$
\mathrm{C}_{2} \mathrm{~F}_{4}(\mathrm{~g})+2 \mathrm{SiO}(\mathrm{g})=\mathrm{SiC}+\mathrm{SiF}_{4}(\mathrm{~g})+\mathrm{CO}_{2}(\mathrm{~g}) .
$$



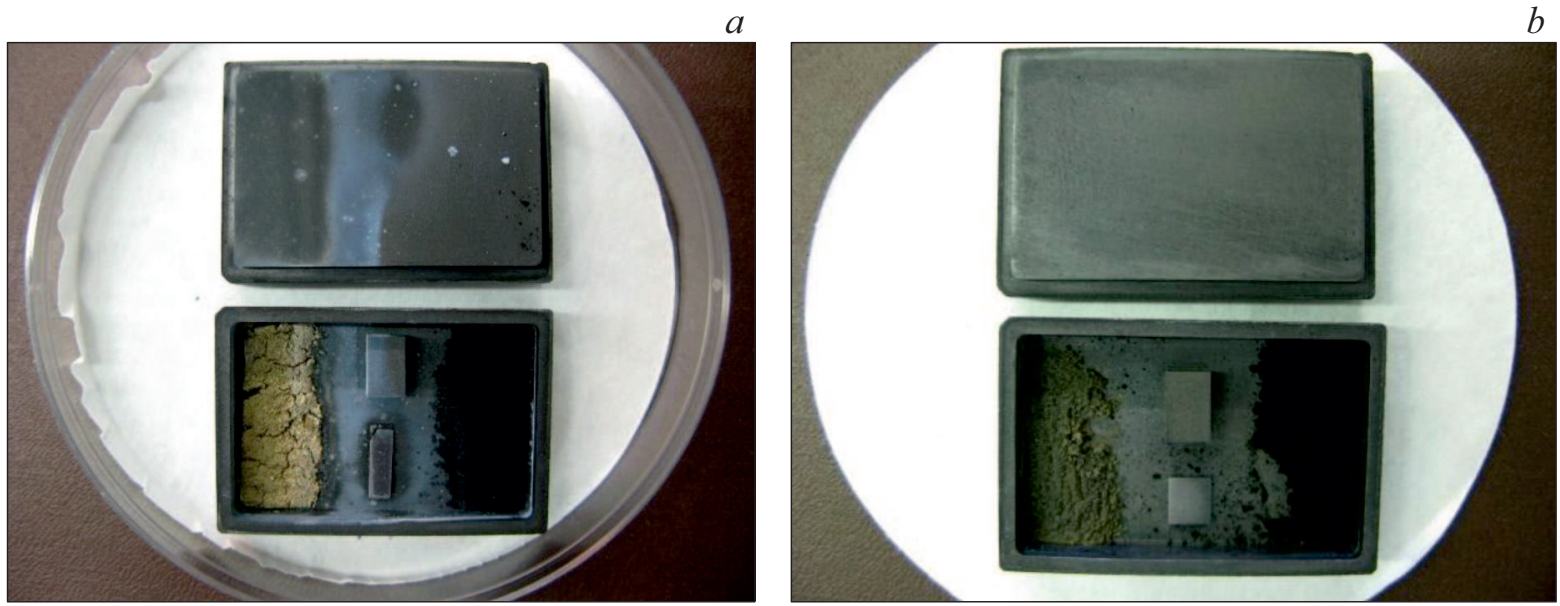

Рис. 12. Фото кассет и их крышек после отжига при $1100^{\circ} \mathrm{C}: a-$ процесс $\mathrm{W} 2 ; b-$ процесс $\mathrm{W} 3$.
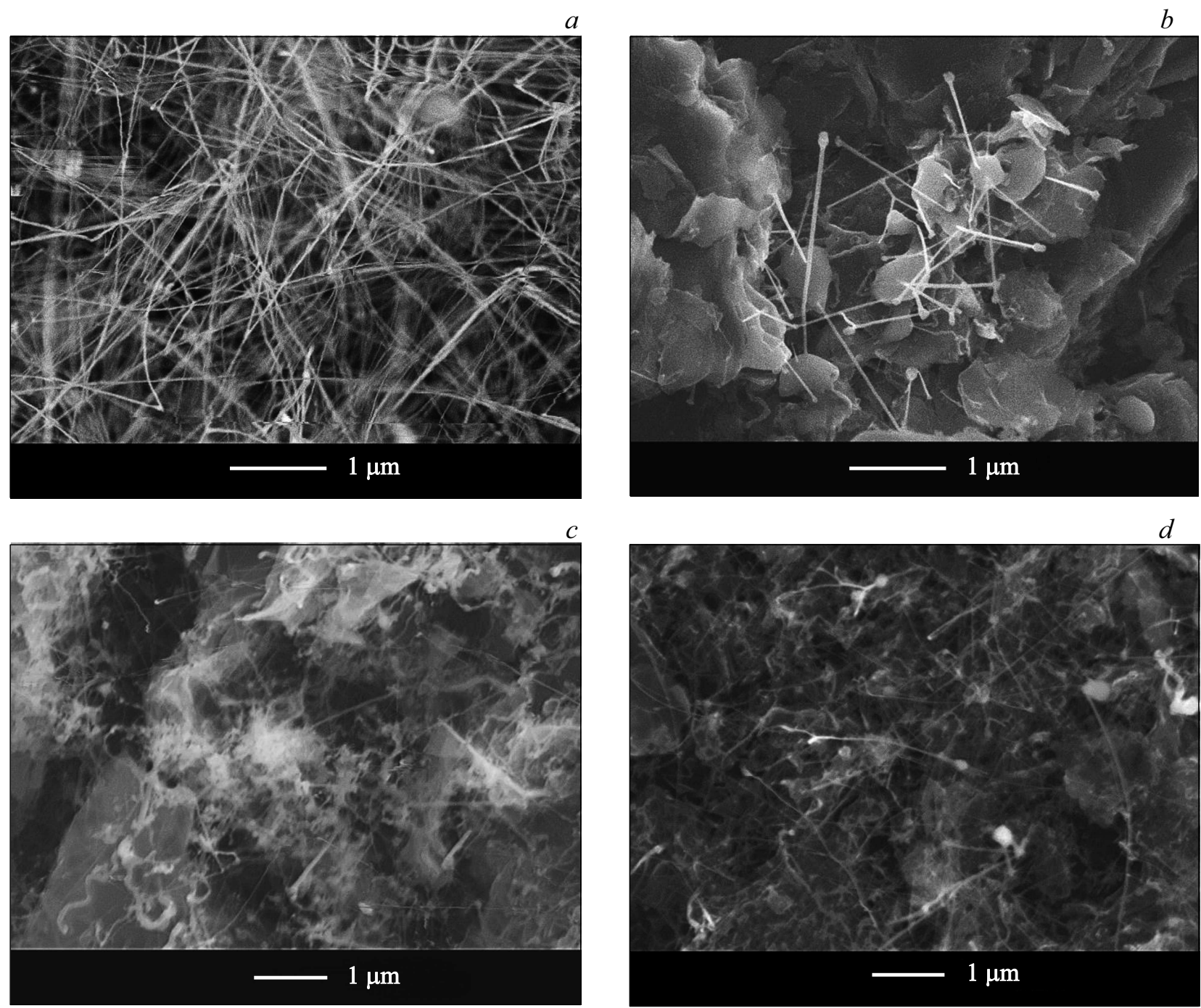

Рис. 13. SЕМ-изображение нанонитей, образовавшихся на графитовой подложке: $a$ и $c-$ со стороны $\left(\mathrm{K}_{2} \mathrm{SiF}_{6}+\mathrm{Si}^{2}\right) ; b$ и $d-$ со стороны $\mathrm{SiO}$ при $1100^{\circ} \mathrm{C}$ (процессы W2 и W3) и при $1000^{\circ} \mathrm{C}$ (процессы W4 и W5). 
Процессы образования $\mathrm{SiC}$ в квазизамкнутом объеме графитовой кассеты с разнесенными в пространстве прекурсорами

\begin{tabular}{c|c|c|c}
\hline Процесс/образец & $T,{ }^{\circ} \mathrm{C}$ & Слева & Справа \\
\hline $\mathrm{W} 2$ & 1100 & $\mathrm{Si}+\mathrm{K}_{2} \mathrm{SiF}_{6}=1: 1$ & \\
$\mathrm{~W} 3$ & 1100 & $\mathrm{SiO}_{2}$ & $\mathrm{CaCO}_{3}+\mathrm{C}=1: 1$ \\
$\mathrm{~W} 4$ & 1000 & $\mathrm{Si}+\mathrm{K}_{2} \mathrm{SiF}_{6}=1: 1$ & \\
$\mathrm{~W} 5$ & 1000 & $\mathrm{SiO}$ &
\end{tabular}

Однако вклад последней гипотетической реакции (12) не может быть существенным из-за того, что в условиях нашего эксперимента, ко времени достижения температуры $1000^{\circ} \mathrm{C}$, концентрация фторуглеродных молекул в газовой фазе оказывается ничтожна мала. Это происходит потому, что они активно реагируют с твердой $\mathrm{SiO}$ уже при низкой температуре (7).

\section{7. Взаимодействие дифторида кремния с моноокисью углерода}

Для выяснения роли фторидов кремния в образовании $\mathrm{SiC}$-нанонитей нами были проведены дополнительные эксперименты, которые имели своей целью сравнить выход нанонитей при взаимодействии между раздельно полученными $\mathrm{CO}$ и $\mathrm{SiF}_{2}$ и между $\mathrm{CO}$ и парами $\mathrm{SiO}$. Смесь порошков $\mathrm{CaCO}_{3}+\mathrm{C}$ насыпалась в правую часть графитовой кассеты - черный порошок на рис. 12, в левую часть насыпалась либо смесь $\mathrm{K}_{2} \mathrm{SiF}_{6}+\mathrm{Si}$ (рис. 12, $a$ ) либо порошок $\mathrm{SiO}$ (рис. 12,b). Между левой и правой кучками порошков располагались подложки из графита и монокристаллического кремния. Печь нагревали до $1100^{\circ} \mathrm{C}$ или $1000^{\circ} \mathrm{C}$, продували аргоном и медленно вдвигали кассету с образцами ( 5 мин). Отжиг проводили в течение 1 ч. После этого кассету выдвигали на край трубы и охлаждали в Ar.

При отжиге происходило термическое разложение $\mathrm{CaCO}_{3}$ и в квазизамкнутом объеме кассеты в присутствии сажи образовывался угарный газ. (Для разложения карбоната кальция на оксид кальция и углекислый газ требуется температура $T=900-1000^{\circ} \mathrm{C}$ ):

$$
\begin{gathered}
\mathrm{CaCO}_{3}(\mathrm{~s})=\mathrm{CaO}(\mathrm{s})+3 \mathrm{CO}_{2}(\mathrm{~g}), \\
\mathrm{CO}_{2}(\mathrm{~g})+\mathrm{C}(\mathrm{s})=2 \mathrm{CO}(\mathrm{g}) .
\end{gathered}
$$

Источником $\mathrm{SiF}_{4}$ служил гексафторсиликат калия, который также разлагается при $T \sim 1000^{\circ} \mathrm{C}$, что в присутствии кремния приводит к образованию газообразного $\mathrm{SiF}_{2}$ :

$$
\begin{gathered}
\mathrm{K}_{2} \mathrm{SiF}_{6}(\mathrm{~s})=\mathrm{SiF}_{4}(\mathrm{~g})+2 \mathrm{KF}(\mathrm{s}), \\
\mathrm{SiF}_{4}(\mathrm{~g})+\mathrm{Si}(\mathrm{s})=2 \mathrm{SiF}_{2}(\mathrm{~g}) .
\end{gathered}
$$

Обозначения и условия проведенных экспериментов приведены в таблице.

На фотографиях кассет после вскрытия (рис. 12) видно, что в процессе W2 произошло активное образование нанонитей $\mathrm{SiC}$ (голубой налет на крышке, дне кассеты и графитовой подложке). SEM-изображение этих нанонитей приведено на рис. 13,a. В процессе W3 нанонити тоже образовались (см. рис. 13, $b$ ), но количество их было существенно меньше и поэтому голубой налет незаметен (рис. 12,b). При температуре отжига $1000^{\circ} \mathrm{C}$ нанонитей в обеих кассетах становится меньше, и их толщина уменьшается (рис. 13, $c$ и $d$ ). На изображении 13, c (эксперимент W4 при $1000^{\circ} \mathrm{C}$ ) так же, как и на рис. 10, $a$, видны связанные с нанонитями выделения другой формы. Появление альтернативных форм роста $\mathrm{SiC}$ при снижении температуры, может быть вызвано снижением плотности микрокапель жидкой силикатной фазы, являющихся затравками для роста нитевидных кристаллов, или же повышением их вязкости, затрудняющим диффузионный перенос молекул к ростовой поверхности.

По характеру ТЕМ-изображений нанонитей, сформировавшихся в процессах W2 и W3, можно заключить, что они качественно не отличаются друг от друга и от полученных при взаимодействии $\mathrm{SiO}$ со фторуглеродом (рис. 5). Нанонити имеют такую же фрагментированную структуру с чередованием политипов при некотором преобладании областей $\beta$ - $\mathrm{SiC}$ и со множеством дефектов упаковки, перпендикулярных направлению роста нанонитей. Похожая структура $\mathrm{SiC}$-нанонитей наблюдалась ранее в работах других авторов $[2,7,8,10,17]$.

\section{8. Обсуждение результатов}

Проведенные эксперименты показали, что нанонити $\mathrm{SiC}$ появляются в обоих предельных случаях: когда $\mathrm{CO}$ сосуществует в газовой фазе только со фторидами кремния и когда взаимодействует только с парами $\mathrm{SiO}$. Однако в первом случае процесс кристаллизации $\mathrm{SiC}$ может успешно протекать в области относительно низких температур $\left(<1100^{\circ} \mathrm{C}\right)$, когда давление паров $\mathrm{SiO}$ оказывается недостаточно высоким для активного роста нанонитей. Во время отжига смесей фторуглерода с моноокисью кремния вклад в образование нанонитей $\mathrm{SiC}$ дают оба газообразных компонента $\mathrm{SiF}_{2}$ и $\mathrm{SiO}$. Тем не менее, поскольку большая часть фторуглерода разлагается и реагирует с $\mathrm{SiO}$ уже при температуре $\sim 600^{\circ} \mathrm{C}$ (реакция 7), а затем газообразные продукты вытесняются из квазизамкнутого объема кассеты накопившимся давлением, то количество $\mathrm{SiF}_{2}$, способного образоваться по реакции (10) при температуре $>1000^{\circ} \mathrm{C}$ и участвовать в кристаллизации нанонитей, оказывается тоже невелико. Тем не менее присутствие дифторида кремния приводит к заметной интенсификации процесса формирования нанонитей.

До сих пор для получения $\mathrm{SiC}-$ нанонитей из галогенидов кремния использовался только $\mathrm{SiCl}_{4}$. Его взаимодействие с $\mathrm{CCl}_{4}$ [18] или с этоксиэтанолом [19] в жидкой фазе при повышенных давлениях проводилось в присутствии восстановителей $\mathrm{Na}$ или $\mathrm{Mg}$ соответственно. Хотя авторы не указывают на это, образование $\mathrm{SiC}$ также, повидимому, происходило с участием восстановленного на 
металле дигалогенида кремния $\mathrm{SiCl}_{2}$. В этом контексте исследование взаимодействия различных дигалогенидов кремния с такими углеродсодержащими соединениями, как угарный газ или непредельные углеводороды, может оказаться весьма полезным для разработки новых, более простых и производительных методов получения карбида кремния и его нитевидных кристаллов.

Интересно также обратить внимание на то, что при достаточно высокой плотности образовавшихся из газовой фазы нанонитей $\mathrm{SiC}$ покрытые ими поверхности приобретают выраженный голубой цвет (рис. 1, $a, 10, d$, 11 и $12, a)$, о чем не упоминается ни в одной из известных нам работ. Однако известно, что голубой цвет присущ объемному $6 H$-SiC (ширина запрещенной зоны $E_{g}=3.05$ эВ), легированному алюминием [20], и что максимумом интенсивности в спектре фотолюминесценции нанонитей кубического $\mathrm{SiC}$ наблюдается в синей области [10]. Авторы работы [21] связывают наблюдавшуюся ими голубую эмиссию из нанонитей на базе $\beta$-SiC $\left(E_{g}=2.36\right.$ эВ $)$ с эффектом размерного квантования в наноструктурированных кристаллах с микродвойниками. Проведенные нами эксперименты показывают, что наблюдаемая окраска полученных скоплений полиморфных нанонитей $\mathrm{SiC}$ не связана с химической природой компонентов, участвующих в кристаллизации. Поэтому нет оснований полагать, что видимый цвет нанокристаллов $\mathrm{SiC}$ обусловлен присутствием в них неконтролируемых примесных центров. Причину обсуждаемого явления, по-видимому, следует искать в фазовом составе полученных нанонитей, содержащих фрагменты широкозонных гексагональных политипов $\mathrm{SiC}$, и в размерном квантовании, обусловленном двойниками и фазовыми границами между сопряженными нанообластями. Однако проверка такой версии требует проведения специальных исследований.

\section{9. Заключение}

1. Обнаружено образование нитевидных нанокристаллов $\mathrm{SiC}$ в процессе отжига смесей монофторида углерода с моноокисью и двуокисью кремния при $T>1000^{\circ} \mathrm{C}$.

2. Показано, что в рассматриваемых системах происходит два параллельных химических процесса, приводящих к кристаллизации $\mathrm{SiC}$-нанонитей. Источником углерода для синтеза $\mathrm{SiC}$ в обоих случаях выступает $\mathrm{CO}$, а источниками кремния служат газообразные $\mathrm{SiO}$ и $\mathrm{SiF}_{2}$. При $T<1200^{\circ} \mathrm{C}$ доминирующей реакцией, определяющей выход нанонитей $\mathrm{SiC}$, становится реакция с $\mathrm{SiF}_{2}$.

3. Специальным экспериментом продемонстрировано образование $\mathrm{SiC}-$ нанонитей из газовой фазы, содержащей $\mathrm{SiF}_{2}$ и $\mathrm{CO}$ и не содержащей паров $\mathrm{SiO}$.

4. С помощью рентгеновской дифрактометрии в образцах, полученных в результате совместного отжига порошков $\mathrm{SiO}$ и $\mathrm{CF}_{x}$, выявлено образование фазовых выделений карбида кремния, преимущественно кубического политипа.
5. Просвечивающая электронная микроскопия показала, что образовавшиеся при этом нитевидные кристаллы карбида кремния представляют собой цепочки когерентно связанных друг с другом областей, принадлежащих различным политипам с некоторым преобладанием $\beta$ - $\mathrm{SiC}$ и со множественными дефектами упаковки, расположенными перпендикулярно базовому направлению роста нитей вдоль кристаллографического направления $\langle 111\rangle$.

\section{Благодарности}

Электронно-микроскопические исследования выполнены с использованием оборудования Федерального ЦКП „Материаловедение и диагностика в передовых технологиях“, поддержанного Министерством образования и науки России.

\section{Конфликт интересов}

Авторы заявляют, что у них нет конфликта интересов.

\section{Список литературы}

[1] T. Tiegs. In: Handbook of ceramic composites, ed. by N.P. Bansal (N. Y., Kluwer Academic Publishers, 2005) p. 307.

[2] S. Chen, W. Li, X. Li, W. Yang. Prog. Mater. Sci., 104, 138 (2019).

[3] https://spectrum.ieee.org/energywise/green-tech/fuel-cells/ startup-advano-silicon-lithium-ion-batteries

[4] Н.В. Латухина, А.С. Рогожин, С. Сайед, В.И. Чепурнов. Изв. вузов. Материалы электронной техники, 17 (4), 284 (2014).

[5] А.В. Павликов, Н.В. Латухина, В.И. Чепурнов, В.Ю. Тимошенко. ФТП, 51 (3), 421 (2017).

[6] M. Saito, S. Nagashima, A. Kato. J. Mater. Sci. Lett., 11, 373 (1992).

[7] W-S. Seo, K. Koumoto. J. Am. Ceram. Soc., 79(7), 1777 (1996).

[8] W-S. Seo, K. Koumoto. J. Am. Ceram. Soc., 83 (10), 2584 (2000).

[9] D. Zhang, A. Alkhateeb, H. Han, H. Mahmood, D.N. Mcllroy, M.G. Norton. Nano Lett., 3 (7), 983 (2003).

[10] D-H. Wang, D. Xu, Q. Wang, Y-J. Hao, G-Q. Jin, X-Y. Guo, K.N. Tu. Nanotechnology, 19, 215602 (2008).

[11] G.Z. Yang, H. Cui, Y. Sun, L. Gong, J. Chen, D. Jiang, C.X. Wang. J. Phys. Chem. C, 113, 15969 (2009).

[12] Е.В. Астрова, В.П. Улин, А.В. Парфеньева, В.Б. Воронков. Письма ЖТФ, 45 (13), 29 (2019).

[13] E.V. Astrova, V.P. Ulin, A.V. Parfeneva, A.M. Rumyantsev, V.B. Voronkov, A.V. Nashchekin, V.N. Nevedomskiy, Y.M. Koshtyal, M.V. Tomkovich. J. Alloys Compd., 826, 154242 (2020).

[14] Е.В. Астрова, А.В. Парфеньева, А.М. Румянцев, В.П. Улин, М.В. Байдакова, В.Н. Неведомский, А.В. Нащекин. Письма ЖТФ, 46 (3), 14 (2020).

[15] JCPDS-International Centre for Diffraction Data http://www.icdd.com

[16] База данных Термические Константы Веществ: электронное издание справочника. http://www.chem.msu.ru/cgi-bin/ tkv.pl?show=welcome.html/welcome.html 
[17] Y. Zhang, X. Han, K. Zheng, Z. Zhang, X. Zhang, J. Fu, Y. Ji, Y. Hao, X. Guo, Zh. Wang. Adv. Funct. Mater., 17, 3435 (2007).

[18] Q. Lu, J. Hu, K. Tang, Y. Qian, G. Zhou, X. Liu, J. Zhu. Appl. Phys. Lett., 75, 507 (1999).

[19] G. Xi, Y. Liu, X. Liu, X. Wang, Y. Qian. J. Phys. Chem. B., 110, 14172 (2006).

[20] M.N. Yolder, R.F. Davis. Nav. Res. Rev., XL, 26 (1988).

[21] X. Fu, D. Wang. Appl. Surf. Sci., 493, 497 (2019).

Редактор А.Н. Смирнов

\section{Interaction of fluorocarbon with silicon monoxide and processes of SiC nanowires formation}

E.V. Astrova, V.P. Ulin, A.V. Parfeneva,

A.V. Nashchekin, V.N. Nevedomskiy, M.V. Baidakova

loffe Institute,

194021 St. Petersburg, Russia

Abstract When studying the processes of thermal carbonization of silicon monoxide in the presence of non-stoichiometric carbon monofluoride, it was found that increasing the annealing temperature of mixtures of $\mathrm{SiO}$ and $\mathrm{CF}_{x}$ powders in a quasiclosed volume to $1000^{\circ} \mathrm{C}$ and higher leads to the release of whiskerlike $\mathrm{SiC}$ nanocrystals. The studies showed that in parallel with the known crystallization of $\mathrm{SiC}$ nanowires as a result of the interaction of $\mathrm{SiO}$ vapors with carbon monoxide, previously undescribed interaction of $\mathrm{CO}$ with gas-phase silicon difluoride $\mathrm{SiF}_{2}$ takes part in their formation. At temperatures below $1200^{\circ} \mathrm{C}$, this reaction is dominant, making the largest contribution to the yield of $\mathrm{SiC}$ nanowires. 